ISSN : $1225-9918$

\title{
Retinoic Acid Potentiates Nitric Oxide-Induced Dedifferentiation through the ERK Pathway in Rabbit Articular Chondrocytes
}

\author{
Seon Mi Yu and Song Ja Kim*
}

Department of Biological Sciences, College of Natural Sciences, Kongiu National University, Gongju, Chungnam 314701, Korea

Received December 31, 2010 /Accepted March 26, 2011

\begin{abstract}
Retinoic acid (RA), a metabolite of vitamin A, is known to regulate dedifferentiation of rabbit articular chondrocytes. The regulatory mechanism of dedifferentiation by RA is not yet understood. Thus, the effect of RA on the regulation of nitric oxide (NO)-induced dedifferentiation was investigated in rabbit articular chondrocytes. RA caused loss of the differentiated chondrocyte phenotype as demonstrated by inhibition of type II collagen expression and proteoglycan synthesis. RA also accelerated NO-induced dedifferentiation in rabbit articular chondrocytes as detected by expression of type II collagen and Sox-9 using Western blot analysis and production of sulfated proteoglycan using Alcain blue staining. Further, RA potentiated NO-induced activation of ERK. Inhibition of ERK with PD98059 (PD) recovered the expression of type $\Pi$ collagen and Sox- 9 and production of sulfate proteoglycan in NO-induced dedifferentiated chondrocytes by RA treatment. Our findings suggest that RA accelerates NO-induced dedifferentiation of rabbit articular chondrocytes via the ERK pathway.
\end{abstract}

Key words : Chondrocytes, retinoic acid (RA), nitric oxide (NO), dedifferentiation

\section{서 론}

연골 조직은 배 발생단계에서 중간엽 세포로부터 분화하 여 형성된다[1,8,24]. 골 조직 안에 존재하는 분화된 연골 세포 는 collagen, proteoglycan과 같은 연골 조직 특이적인 분자들 을 합성함으로써 항상성을 유지한다[23,25]. 그러나, 이러한 항상성은 관절염과 같은 관절 관련 질환의 발병에 의해 파괴 된다. 관절염에 있어서 연골 조직이 파괴되는 것은 interleukin (IL)-1 $\beta$ 와 같은 염증성 사이토카인류 및 nitric oxide $(\mathrm{NO})$ 와 같은 활성산소에 의해 유도되는 탈분화와 밀접한 관 련이 있다[2,9,11,25].

Sodium nitroprusside $(\mathrm{SNP})$ 는 $\mathrm{NO}$ 의 공여체로서 연골세 포의 탈분화를 유도한다[11,13,14]. NO는 일반적으로 연골 세포의 탈분화를 조절하는 중요한 매개물질로 알려져 있다 [1-3]. NO는 interleukin (IL)-1ß와 같은 염증성 사이토카인 등의 영향으로 합성된다. $\mathrm{NO}$ 의 합성은 Matrix metalloproteinases (MMPs)의 활성을 유도하고, type П collagen 의 발현과 proteoglycan의 합성을 억제하는 것으로 알려져 있다 $[5,27,28]$. NO 합성의 억제는 연골 조직 및 연골세포의 파괴로부터 보호 할 수 있다. NO가 유도하는 연골세포의 탈분화는 mitogen-activated protein (MAP) kinase의 아형 인 extracellular signal-regulated protein kinase (ERK)와 p38에 의해 조절된다. 또한 $\mathrm{NO}$ 생성은 protein kinase C

\footnotetext{
${ }^{*}$ Corresponding author Tel : +82-41-850-8507, Fax : +82-41-850-0927 E-mail : ksj85@kongju.ac.kr
}

(PKC) a와 ㄱㅇㅢ 억제를 유도하여 탈분화를 유도하는 것으로 알려져 있다[33].

Retinoic acid (RA)는 Vitamine A의 유도체로써 연골 조직 과 골격 형성의 중요한 조절자로 알려져 있다[19,30]. RA는 중간엽 세포의 연골 조직으로의 분화를 억제하고 연골세포의 탈분화를 유도하는 것으로 알려져 있다 $[4,6,13,29,31]$. 그러나 연골세포의 분화에 있어서 $\mathrm{RA}$ 의 분자적 기작은 아직 명확히 알려진 바가 없다. 따라서, 본 연구에서는 탈분화의 유도 물질 로 알려진 $\mathrm{SNP}$ 를 함께 처리하여 RA가 유도하는 탈분화와 관 련한 신호전달경로를 밝히고자 하였다. 그 결과, RA는 연골 세포의 탈분화에 있어서 중요한 역할을 하는 ERK의 활성을 조절하여 연골세포 분화의 표지 단백질인 type II collagen의 발현과 proteoglycan의 합성을 억제함으로써 SNP가 유도하 는 탈분화를 더욱 촉진시키는 것을 확인 할 수 있었다.

\section{재료 및 방법}

\section{Cell culture}

2주된 New Zealand White 종의 토끼를 사용하여 무릎관 절에서 연골 조직을 분리해 낸 후, $50 \mu \mathrm{g} / \mathrm{ml}$ 의 streptomycin, 50 units $/ \mathrm{ml}$ 의 penicillin이 함유된 Dulbecco's modified Eagle's medium (DMEM, Gibco-BRL, Gaithersburg, MD)에 collagenase를 $0.2 \%$ 가 되도록 섞어 $37^{\circ} \mathrm{C}$ 로 유지되는 $\mathrm{CO}_{2}$ incubator에서 7시간 동안 조직을 세포로 분리하는 작업을 시행 하였다. 조직이 모두 세포로 분리되었으면 원심분리(1,000 $\mathrm{rpm}, 10$ 분)하여 단세포만을 모았다. 모은 세포를 $10 \%$ 의 FBS 
(Fetal bovine serum), $50 \mathrm{\mu g} / \mathrm{ml}$ 의 streptomycin, 50 units $/ \mathrm{ml}$ 의 penicillin이 함유된 Dulbecco's modified Eagle's medium

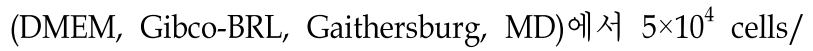
dish의 밀도로 배양하였다. 배양액은 이틀에 한 번 교체를 했 으며, 세포 밀도가 약 70 80\% 정도 되었을 때, 시약을 처리하 였다.

\section{Western blot analysis}

$50 \mathrm{mM}$ Tris- $\mathrm{HCl}, \mathrm{pH} 7.4,150 \mathrm{mM} \mathrm{NaCl}, 1 \%$ Nonidet P-40, 0.1\% Sodium dodecyl sulfate를 포함한 buffer에 다양한 protease inhibitor $[10 \mu \mathrm{g} / \mathrm{ml}$ leupeptin, $10 \mu \mathrm{g} / \mathrm{ml}$ pepstatin A, $10 \mu \mathrm{g} / \mathrm{ml}$ aprotinin, $1 \mathrm{mM}$ 4-(2-aminoethyl) benzensulfonyl fluoride]와 phosphatase inhibitor [1 mM NaF, $1 \mathrm{mM}$ $\mathrm{Na}_{3} \mathrm{VO}_{4}$ ]를 첨가한 후 lysis buffer를 사용하여 단백질을 lysis 시켰다. 이 단백질을 $8 \%$ SDS-polyacrylamide gel에 전기영동 하여 Nitrocellulose 막으로 이동시켰다. 후에 일차 항체 type II collagen (Santa Cruz, CA, USA), Sox-9 (Santa Cruz), pERK (Santa Cruz), actin (Santa Cruz)과 이차 항체를 붙인 후 X-ray film에 감광시켰다.

\section{Determination of chondrocyte phenotype}

연골세포의 분화 정도는 $0.1 \%$ Alcian Blue 용액을 사용 하여 sulfated proteoglycan의 축적량을 측정하였다. 세포 를 PBS로 세 번 수세한 뒤, Kahle's solution에서 10분 동 안 고정한 뒤 다시 PBS로 세 번 수세하였다. 그 후 alcian blue staining solution으로 12시간 이상 염색하였다. $0.1 \mathrm{~N}$ $\mathrm{HCl}$ 로 두 번 수세한 뒤 $4 \mathrm{M}$ guanidine $\mathrm{HCl}$ 을 넣고 약 12 시간 정도 shaking하였다. 96 well plate에 약 $180 \mu \mathrm{l} /$ well 씩 넣어서 ELISA reader에서 $600 \mathrm{~nm}$ 로 흡광도 값을 측정 하였다.

\section{Immunofluorescence staining}

배양한 연골세포를 $3.5 \%$ paraformaldehyde로 10분 동안 상온에서 고정시켰으며, 고정된 세포는 PBS로 두 번 수세 한 뒤 $0.1 \%$ Triton X-100을 이용하여 세포막 투과성을 높여 주었 다. 고정된 세포는 두 시간 동안 상온에서 일차항체인 type II collagen (Santa Cruz)과 반응시켰으며, 세 번 수세한 뒤 형광단백질이 부착되어 있는 이차 항체와 한 시간 동안 반응 시켰다. 두 번 수세 한 뒤, 그 후 형광현미경 하에서 세포 내 type I collagen의 발현량을 확인하였다.

\section{Statistics}

각 실험에서 사용한 대조군 및 시약처리군들 간의 유의 한 차이가 있는지 알아보기 위해 one-way ANOVA 프로 그램을 사용하여 측정값의 차이 및 유의성 정도를 파악하
였다. $p<0.05$ 인 경우 유의성이 있는 것으로 판단하였으며 본 실험의 결과는 네 차례의 실험 중 평균적인 결과를 사 용하였다.

\section{결 과}

\section{$\mathrm{RA}$ 에 의한 연골세포의 탈분화 촉진}

기존에 연구된 바에 의하면, $\mathrm{NO}$ 의 공여체인 $\mathrm{SNP}$ 를 연골 세포에 처리하면 연골세포의 탈분화를 유도한다는 연구 내용 이 보고된 바 있다[18]. 따라서 본 연구에서는 토끼 관절 연골 세포의 탈분화를 유도하는 시약으로 알려져 있는 RA를 SNP 와 함께 처리하였을 때. 연골세포의 분화에 미치는 효과 및 그 신호전달경로 구축에 관한 연구를 진행하였다.

우선 연골세포의 분화 정도를 나타내는 단백질로 알려져 있는 proteoglycan의 합성량을 측정하기 위하여 Alcian blue staining을 수행하였다(Fig. 1). RA는 시간 의존적으로 proteoglycan의 합성량을 감소시키는 것을 확인 할 수 있었다 (Fig. 1A). 또한 RA에 의해 감소된 proteoglycan의 합성량은 $\mathrm{SNP}$ 를 함께 처리한 군에서 시간 의존적으로 더욱 감소되는 것을 확인 할 수 있었다(Fig. $1 \mathrm{~B}$ and C). 따라서, 탈분화와 관 련 있는 신호전달경로를 알기 위하여 연골세포 분화의 표지 단백질로 알려져 있는 type II collagen 및 Sox-9의 발현량을 Western blot analysis를 통해 확인 해 본 결과, RA를 단독으 로 처리한 군 보다(Fig. $2 \mathrm{~A}) \mathrm{SNP}$ 와 RA를 함께 처리한 군에서 (Fig. 2B) type II collagen 및 Sox-9의 발현량이 더욱 감소하 는 것을 확인 할 수 있었다(Fig. 2). RA를 처리 한 후 24시간이 지난 연골세포의 경우 대조군 세포와 비교 했을 때 type ㅍ collagen의 발현량이 약 2.5배 감소 하였으며(Fig. 2A. right panel), Sox-9의 경우 약 5 배 정도 발현량이 감소하는 것을 확 인 할 수 있었다(Fig. 2B. right panel). Western blot analysis 을 수행하여 얻은 결과 값은 image J 프로그램을 통해 수치화 하였다(Fig. 2A and B. right panels). 또한 세포 수준에서 좀 더 효과적으로 RA의 효과를 입증하기 위하여 면역 형광 염색 법을 수행한 결과, $\mathrm{RA}$ 를 단독으로 처리한 군보다 $\mathrm{SNP}$ 를 함 께 처리한 군에서 type II collagen의 발현량이 현저히 감소 하는 것을 확인 할 수 있었다(Fig. 2C). 이와 같은 결과는 RA 가 $\mathrm{SNP}$ 에 의해 유도되는 탈분화를 더욱 촉진시킨다는 것을 말해주는 결과라 할 수 있었다(Fig. 2).

\section{ERK 신호전달경로를 통한 RA 유도 탈분화의 조절}

기존에 SNP를 처리하여 type ㅍ collagen 발현량이 감소할 때 ERK의 활성이 증가된다는 논문이 보고 된 바 있다 $[15,18,32]$. 즉 이와 같은 결과는 SNP가 유도하는 연골세포의 탈분화는 ERK의 활성과 밀접한 관련이 있다라는 것을 말해 주는 연구 결과라 할 수 있다. 따라서, RA가 유도하는 탈분화 
A

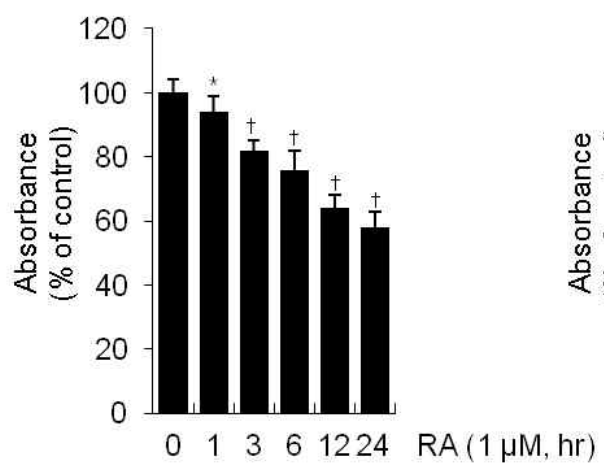

C
B

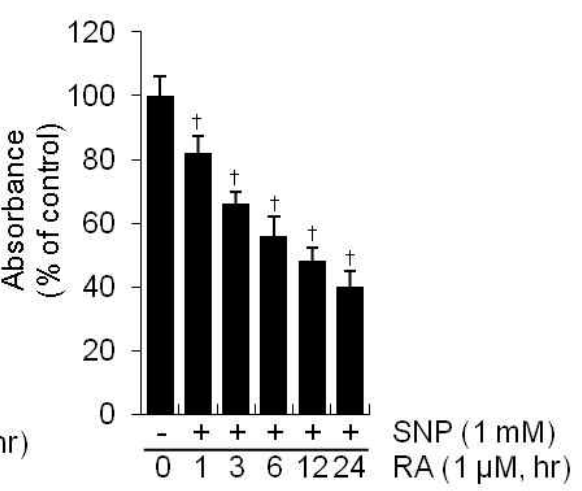

A

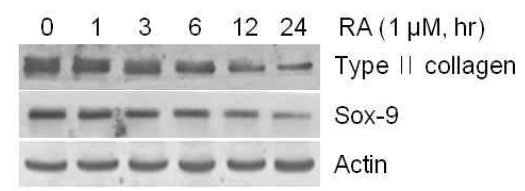

B

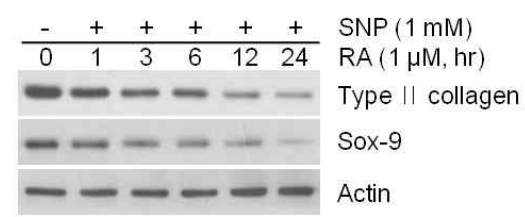

C
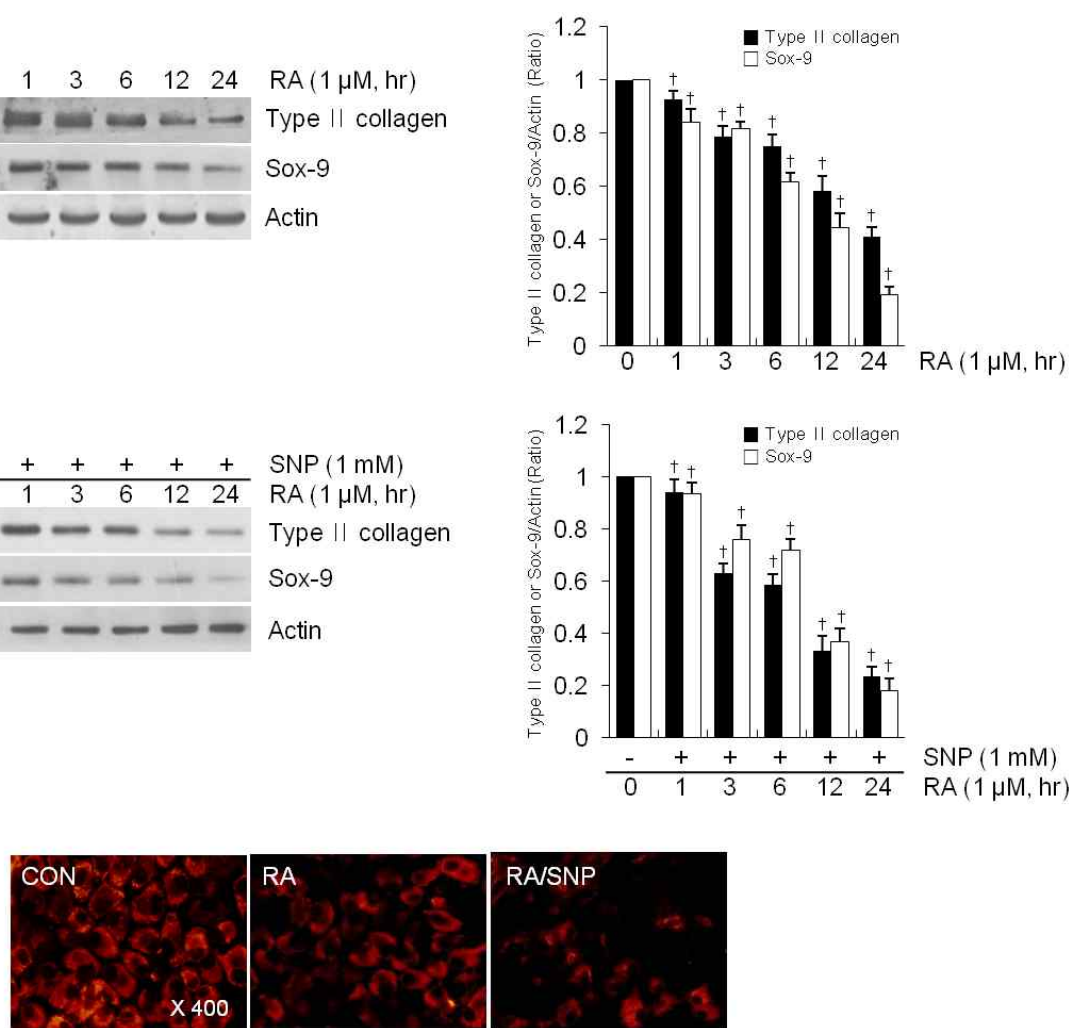

Fig. 1. RA accelerates NO-induced dedifferentiation. Chondrocytes were untreated or treatedwith 1 $\mu \mathrm{M}$ RA without or with $1 \mathrm{mM}$ SNP for the indicated time periods (A and B). Accumulation of sulfated proteoglycan was determined by Alcain blue staining. Primary chondrocytes were untreated or treated with $1 \mu \mathrm{M}$ RA without or with $1 \mathrm{mM}$ SNP for $24 \mathrm{hr}$. Accumulation of sulfated proteoglycan was determined by Alcain blue staining (C). The data represent a typical experiment, and similar results were obtained from four independent experiments (A-C).

Fig. 2. RA promotes NO-induced dedifferentiation. Primary chondrocytes were untreated or treated with $1 \mu \mathrm{M}$ RA without or with $1 \mathrm{mM} \mathrm{SNP}$ for the indicated time periods (A and B). Expression of type II collagen and Sox-9 was determined by Western blot analysis (A and B. left panels). Expression of actin was used as a loading control (A and B). The relative amounts of type II collagen and Sox-9 were quantified by densitometric measurement (image J) (A and B. right panels). Rabbit articular chondrocytes were untreated or treated with $1 \mu \mathrm{M}$ RA without or with $1 \mathrm{mM} \mathrm{SNP}$ for $24 \mathrm{hr}$ (C). Expression of type II collagen was determined by immunofluorescence staining (C). Data are presented as results of a typical experiment and as mean values with standard deviation (A-C). ${ }^{*}, p<0.05,{ }^{\dagger}<0.01$ compared with untreated cells. 
에 있어서도 ERK의 활성이 중요한 역할을 하는지 알아보기 위해 RA를 처리한 후, ERK의 활성을 확인 할 수 있는 $\mathrm{pERK}$ 의 발현량을 확인해 보았다. 그 결과 RA를 처리한 후 약 1 시 간이 지난 후 $\mathrm{pERk}$ 의 발현이 대조군 세포와 비교 시 약 2.6배 증가하였으며 그 후 서서히 감소되는 것을 확인 할 수 있었다 (Fig. 3A). 이러한 결과는 RA를 단독으로 처리한 군과 비교 했을 때 $\mathrm{SNP}$ 를 함께 처리한 군에서 $\mathrm{RA}$ 를 처리한 후 약 1 시간 이 지난 후 $\mathrm{pERK}$ 의 발현량이 더욱 증가하여 대조군과 비교 했을 때 약 3 배 이상 증가하여 발현되는 것을 확인 할 수 있었 다(Fig. $3 \mathrm{~B}$ ). 또한 pERK의 발현이 SNP처리에 의해 6시간까지 강하게 발현되는 것을 확인 할 수 있었다(Fig. 3B). 이와 같은 결과는 RA가 유도하는 탈분화의 조절에 있어서 ERK 신호전 달경로가 중요한 역할을 한다는 것을 말해준다.

따라서 ERK의 억제자인 PD98059을 사용하여 RA가 유도 하는 탈분화에 미치는 ERK의 역할에 관한 연구를 수행하였 다(Fig. 4). PD98059을 1시간 먼저 처리하여 ERK 신호전달경 로를 차단 한 뒤, $\mathrm{SNP}$ 와 $\mathrm{RA}$ 를 함께 처리하여 $\mathrm{pERK}$, type II collagen, Sox-9의 발현량을 확인해 보았다. 그 결과, PD98059
을 처리한 군에서 RA와 SNP에 의해 감소하였던 type $\Pi$ collagen이 약 3.5배 회복되는 것을 확인 할 수 있었고, Sox-9의 발현량 역시 약 2 배 회복되는 것을 확인 할 수 있었다(Fig. $4 \mathrm{~A}$ ). 이와 같은 결과는 Alcian blue staining을 통해서도 유사 한 경향을 보이는 것을 확인 할 수 있었다(Fig. 4B). 즉, 이러한 모든 결과를 통해 RA는 NO가 유도하는 탈분화를 촉진하고 이와 같은 효과는 ERK 신호전달경로를 통해 조절된다는 것 을 확인 할 수 있었다.

\section{고 찰}

연골의 탈분화, 염증 반응, 세포사멸과 같은 연골의 퇴행 성 변화는 관절염과 같은 관절 질환을 유발한다 $[8,10,20$, 21,25]. 따라서 이와 관련한 단백질 및 유전자의 발굴과 신 호전달경로의 규명은 관절염을 연구하는데 있어서 매우 중 요하다.

$\mathrm{RA}$ 는 배 발생 과정과 세포분화에 있어서 중요한 신호 분 자로 알려져 있다[6,12,26]. 이전에 보고된 연구 내용을 보았
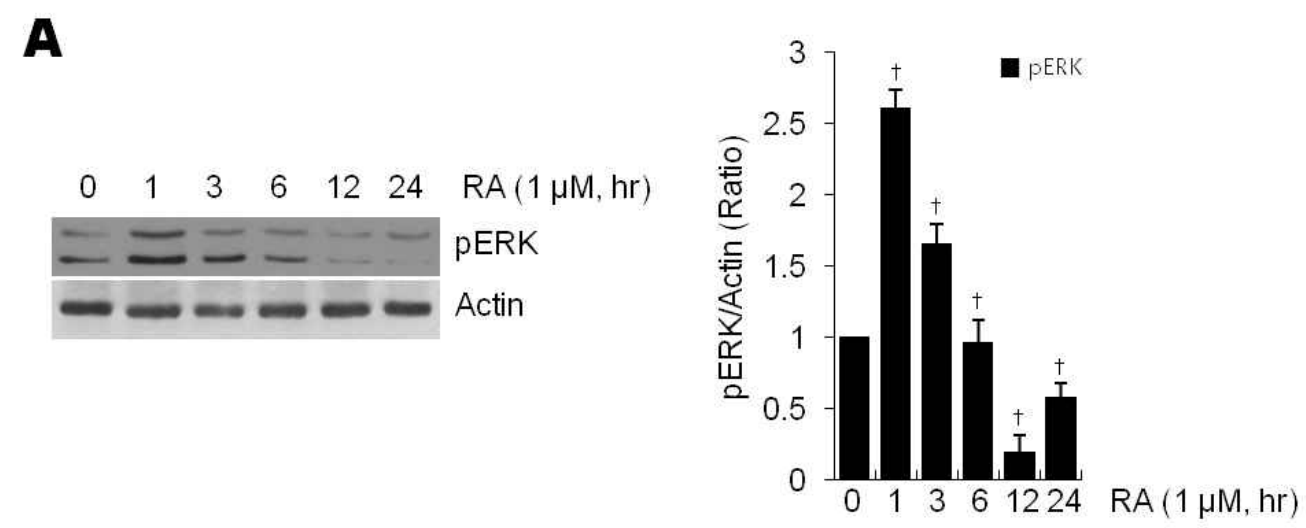

B
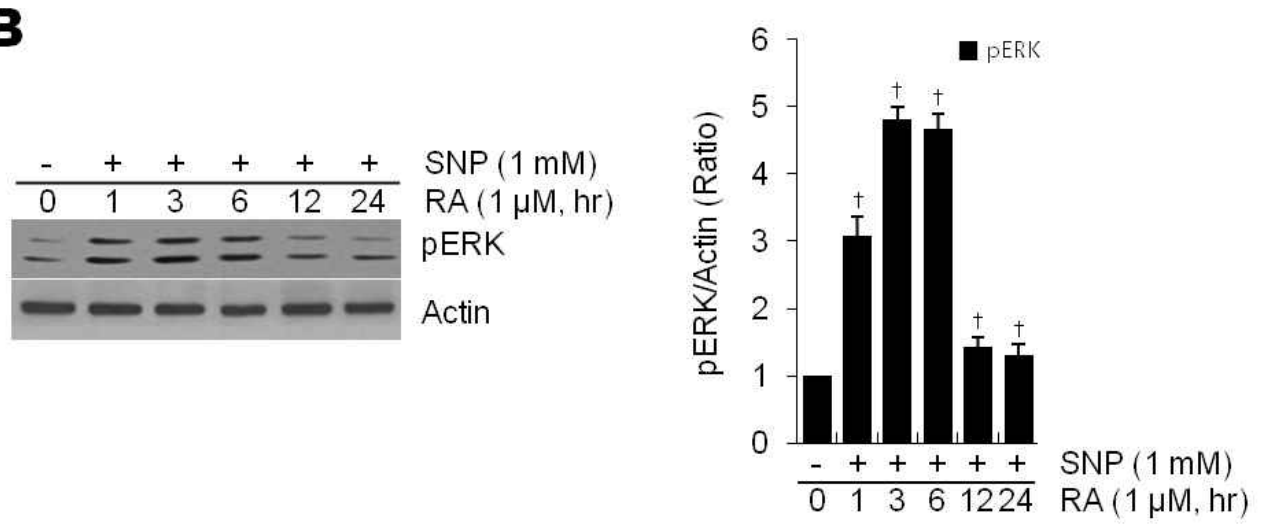

Fig. 3. RA accelerates NO-reduced the activity of ERK. Cells were untreated or treated with $1 \mu \mathrm{M}$ RA without or with $1 \mathrm{mM}$ SNP for the indicated time periods (A and B). Expression of pERK was determined by Western blot analysis. Expression of actin was used as a loading control (A and B. left panels). The relative amounts of pERK were quantified by densitometric measurement (image J) (A and B. right panels). These data are results of a typical experiment (A and B). 

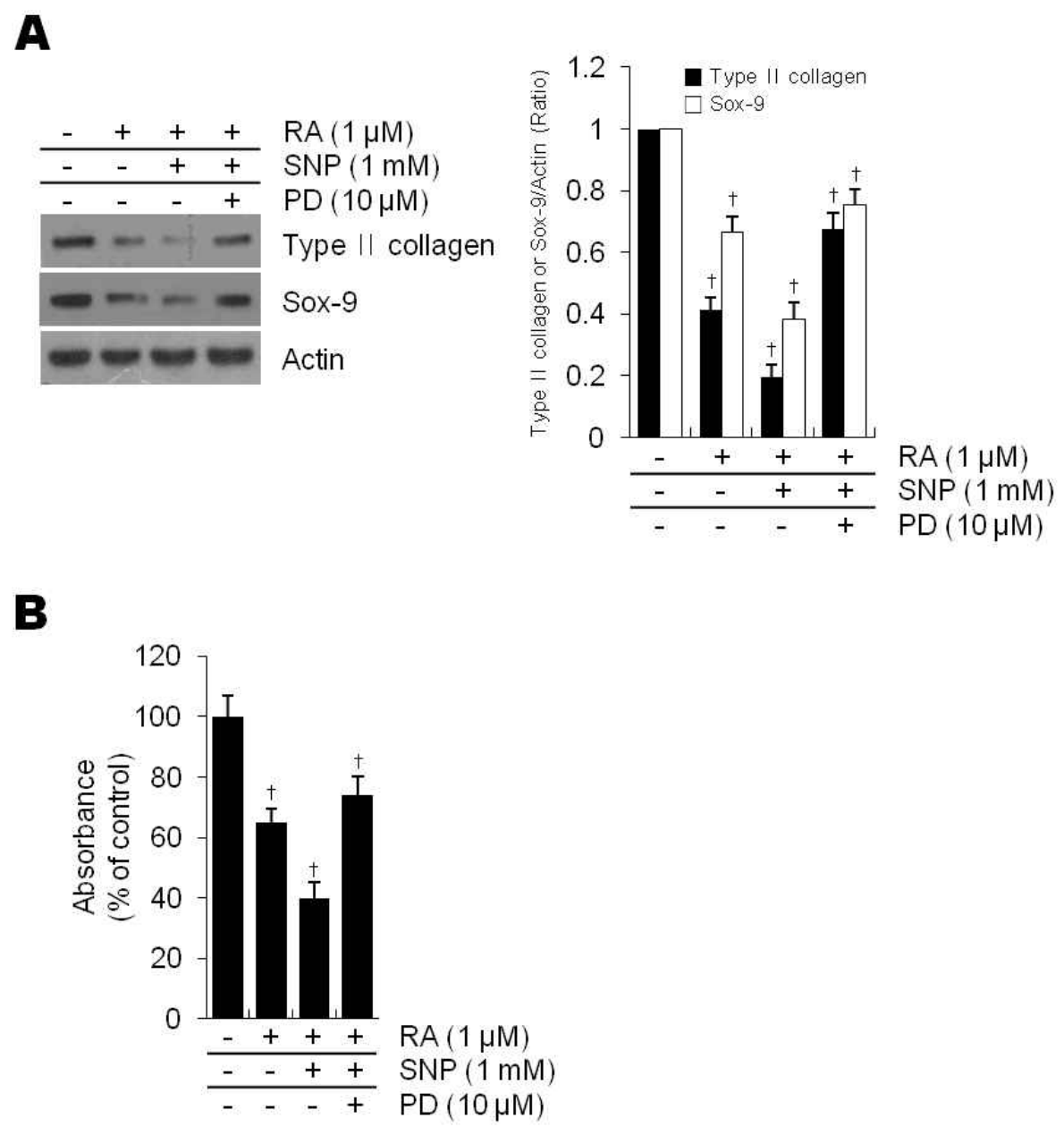

Fig. 4. Inhibition of ERK activity with PD98059 was recovered RA promotes NO-induced dedifferentiation. Articular chondrocytes were untreated or treated with $10 \mu \mathrm{M}$ PD98059 for $1 \mathrm{hr}$ and then treated with $1 \mu \mathrm{M}$ RA without or with $1 \mathrm{mM}$ SNP for $24 \mathrm{hr}$ (A and B). Expressions of pERK, type II collagen and Sox-9 were detected by Western blot analysis. Expressions of actin were used as loading controls (A). The relative amounts of type $\Pi$ collagen and Sox-9 were quantified by densitometric measurement (image J) (A. right panel). Accumulation of sulfated proteoglycan was determined by Alcain blue staining (B). Data are presented as results of a typical experiment and as mean values with standard deviation (A and $\mathrm{B}) .{ }^{*}, p<0.05,{ }^{\dagger}<0.01$ compared with untreated cells.

을 때, 연골세포에 RA를 처리한 결과, $\mathrm{RA}$ 는 간충직세포에 서 연골세포로의 분화를 억제시킨다는 것을 확인 할 수 있 었다[4,6,13,23,31]. RA는 연골 발생 과정 동안 세포간 결합 단백질인 a-catenin, $\beta$-catenin, $\mathrm{N}$-cadherin의 발현을 높게 유지시킴으로써 연골세포의 분화를 억제하는 것을 확인 할 수 있었다[7].

$\mathrm{NO}$ 는 연골세포의 탈분화 및 세포사멸을 조절하는 중요한 물질로 알려져 있다[1-3]. 염증성 사이토카인류의 자극을 받 은 연골세포는 $\mathrm{NO}$ 를 생성하게 되고 이렇게 만들어진 $\mathrm{NO}$ 는 MMPs의 활성을 유도하며[27], type II collagen의 발현량 및 proteoglycan의 합성량을 감소시키고 $[5,28]$, 염증 반응 및 세 포사멸을 유도한다[22]. NO의 공여체인 SNP는 MAP kinase 및 PKC kinase 신호전달경로를 통해 세포의 탈분화 및 세포
사멸, 염증 반응을 조절하는 물질로 알려져 있다[14-18,33]. 그 러나 RA가 유도하는 탈분화가 어떠한 신호전달경로를 통해 조절되는지 명확히 밝혀진 바 가 없다. 따라서 SNP와 함께 처리하여 RA가 유도하는 탈분화와 관련한 신호전달경로를 규명하고자 본 실험을 수행하였다. 연골세포에 RA를 $\mathrm{SNP}$ 와 함께 처리한 결과 RA는 $\mathrm{SNP}$ 가 유도하는 탈분화를 더욱 더 촉진하는 것을 확인 할 수 있었다. RA를 SNP와 함께 처리 했을 때, RA에 의해 감소된 type II collagen및 Sox-9의 발현 량과 proteoglycan의 합성량 역시 더욱 감소하는 것을 확인 할 수 있었다(Fig. 1 and Fig. 2). 연골세포에서 ERK-1/-2의 활성은 탈분화를 유도하고 p38kinase의 활성은 분화를 유지 시킴으로써 연골세포의 분화 및 탈분화를 상반되게 조절하는 데 관여 함으로써 연골세포의 분화 및 탈분화에 있어서 중요 
한 단백질로 알려져 있다[17,18,33]. 따라서 RA가 유도하는 탈 분화의 조절에 있어서 p38kinase와 ERK-1/-2 신호전달경로 가 관여하고 있는지 SNP를 함께 처리함으로 알아보았다. RA 를 단독으로 처리하였을 때, ERK의 발현량이 초기 시간 때에 (시약 처리 후 한 시간이 지난 후) 증가하는 것을 확인 할 수 있었다. 이와 같은 경향은 SNP를 함께 처리했을 때 더욱 두드 러지는 것을 확인 할 수 있었다(Fig. 3). ERK의 억제자인 PD98059을 처리하여 type II collagen 및 Sox-9의 발현량과 proteoglycan의 합성량을 확인해 본 결과, 감소되었던 type II collagen및 Sox-9의 발현량과 proteoglycan의 합성량이 PD98059 처리에 의해 다시 회복되는 것을 확인 할 수 있었다 (Fig. 4). 이와 같은 결과는 RA가 유도하는 탈분화와 관련한 신호전달경로가 SNP가 유도하는 신호전달경로와 유사한 경 로에 의해 조절 되는 것임을 말해주는 결과라 할 수 있다. 또 한 RA를 처리하였을 때, p38kinase의 활성 역시 증가하는 것 을 확인 할 수 있었으나, p38kinase의 억제자인 SB203580을 처리했을 때 type II collagen및 Sox-9의 발현량과 proteoglycan의 합성량의 변화를 확인 할 수 없었다(data not shown). 즉, 이와 같은 결과는 RA에 의해 유도된 탈분화가 ERK 신호 전달경로를 통해 조절됨을 말해주는 결과라 할 수 있다. 이러 한 연골세포 내에서 일어나는 다양한 반응들의 조절에 있어 서 ERK 신호전달경로 외에 PKC kinase와 같은 다양한 신호 전달경로가 존재하기 때문에, 앞으로도 현재 연구된 결과를 바탕으로 다양하고 구체적인 연구가 더욱 수행 되어야 할 것 으로 생각된다. 이와 같은 연구 결과는 앞으로 관절염과 같은 연골세포의 퇴행과 관련한 질환에 있어서 기초적인 자료로 사용될 수 있을 것으로 기대된다.

\section{감사의 글}

이 논문은 정부(교육과학기술부)의 재원으로 한국연구재 단의 지원을 받아 수행된 연구임(No. 2009-0084569 \& 20100003239).

\section{References}

1. Abramson, S. B., M. Attur, A. R. Amin, and R. Clancy. 2001. Nitric oxide and inflammatory mediators in the perpetuation of osteoarthritis. Curr. Rheumatol. Rep. 3, 535-541.

2. Amin, A. R. and S. B. Abramson. 1998. The role of nitric oxide in articular cartilage breakdown in osteoarthritis. Curr. Opin. Rheumatol. 10, 263-268.

3. Amin, A. R., M. Attur, and S. B. Abramson. 1999. Nitric oxide synthase and cyclooxygenases: distribution, regulation, and intervention in arthritis. Curr. Opin. Rheumatol. 11, 202-209.

4. Biddulph, D. M., M. M. Dozier, N. C. Julian, and L. M.
Sawyer. 1988. Inhibition of chondrogenesis by retinoic acid in limb mesenchymal cells in vitro: effects on PGE2 and cyclic AMP concentrations. Cell Differ. Dev. 25, 65-75.

5. Cao, M., A. Westerhausen-Larson, C. Niyibizi, K. Kavalkovich, H. I. Georgescu, C. F. Rizzo, P. A. Hebda, M. Stefanovic-Racic, and C. H. Evans. 1997. Nitric oxide inhibits the synthesis of type-II collagen without altering Col2A1 mRNA abundance: prolyl hydroxylase as a possible target. Biochem J. 324, 305-310.

6. Cash, D. E., C. B. Bock, K. Schughart, E. Linney, and T. M. Underhill. 1997. Retinoic acid receptor alpha function in vertebrate limb skeletogenesis: a modulator of chondrogenesis. J. Cell Biol. 136, 445-457.

7. Cho, S. H., C. D. Oh, S. J. Kim, I. C. Kim, and J. S. Chun. 2003. Retinoic acid inhibits chondrogenesis of mesenchymal cells by sustaining expression of N-cadherin and its associated proteins. J. Cell Biochem 89, 837-847.

8. DeLise, A. M., L. Fischer, and R. S. Tuan. 2000. Cellular interactions and signaling in cartilage development. Osteoarthritis Cartilage 8, 309-334.

9. Demoor-Fossard, M., P. Galera, M. Santra, R. V. Iozzo, J. P. Pujol, and F. Redini. 2001. A composite element binding the vitamin $\mathrm{D}$ receptor and the retinoic $X$ receptor alpha mediates the transforming growth factor-beta inhibition of decorin gene expression in articular chondrocytes. J. Biol. Chem 276, 36983-36992.

10. Eyre, D. 2002. Collagen of articular cartilage. Arthritis Res. 4, 30-35.

11. Goldring, M. B., J. R. Birkhead, L. F. Suen, R. Yamin, S. Mizuno, J. Glowacki, J. L. Arbiser, and J. F. Apperley. 1994. Interleukin-1 beta-modulated gene expression in immortalized human chondrocytes. J. Clin. Invest. 94, 2307-2316.

12. Hassell, J. R., J. P. Pennypacker, and C. A. Lewis. 1978. Chondrogenesis and cell proliferation in limb bud cell cultures treated with cytosine arabinoside and vitamin A. Exp. Cell Res. 112, 409-417.

13. Jiang, H., D. R. Soprano, S. W. Li, K. J. Soprano, J. D. Penner, M. Gyda $3^{\text {rd }}$, and D. M. Kochhar. 1995. Modulation of limb bud chondrogenesis by retinoic acid and retinoic acid receptors. Int. J. Dev. Biol. 39, 617-627.

14. Kim, S. J. and J. S. Chun. 2003. Protein kinase C alpha and zeta regulate nitric oxide-induced NF-kappa B activation that mediates cyclooxygenase-2 expression and apoptosis but not dedifferentiation in articular chondrocytes. Biochem Biophys. Res. Commun. 303, 206-211.

15. Kim, S. J., S. G. Hwang, I. C. Kim, and J. S. Chun. 2003. Actin cytoskeletal architecture regulates nitric oxide-induced apoptosis, dedifferentiation, and cyclooxygenase-2 expression in articular chondrocytes via mitogen-activated protein kinase and protein kinase C pathways. J. Biol. Chem 278, 42448-42456.

16. Kim, S. J., S. G. Hwang, D. Y. Shin, S. S. Kang, and J. S. Chun. 2002. p38 kinase regulates nitric oxide-induced apop- 
tosis of articular chondrocytes by accumulating p53 via NFkappa B-dependent transcription and stabilization by serine 15 phosphorylation. J. Biol. Chem 277, 33501-33508.

17. Kim, S. J., J. W. Ju, C. D. Oh, Y. M. Yoon, W. K. Song, J. H. Kim, Y. J. Yoo, O. S. Bang, S. S. Kang, and J. S. Chun. 2002. ERK-1/2 and p38 kinase oppositely regulate nitric oxide-induced apoptosis of chondrocytes in association with p53, caspase-3, and differentiation status. J. Biol. Chem 277, 1332-1339.

18. Kim, S. J., H. G. Kim, C. D. Oh, S. G. Hwang, W. K. Song, Y. J. Yoo, S. S. Kang, and J. S. Chun. 2002. p38 kinase-dependent and -independent Inhibition of protein kinase $\mathrm{C}$ zeta and -alpha regulates nitric oxide-induced apoptosis and dedifferentiation of articular chondrocytes. J. Biol. Chem 277, 30375-30381.

19. Kwasigroch, T. E. and D. M. Kochhar. 1980. Production of congenital limb defects with retinoic acid: phenomenological evidence of progressive differentiation during limb morphogenesis. Anat. Embryol. (Berl). 161, 105-113.

20. L'Hermette, M. F., C. Tourny-Chollet, G. Polle, and F. H. Dujardin. 2006. Articular cartilage, degenerative process, and repair: current progress. Int. J. Sports Med 27, 738-744.

21. Martel-Pelletier, J., C. Boileau, J. P. Pelletier, and P. J. Roughley. 2008. Cartilage in normal and osteoarthritis conditions. Best Pract. Res. Clin. Rheumatol. 22, 351-384.

22. Notoya, K., D. V. Jovanovic, P. Reboul, J. Martel-Pelletier, F. Mineau, and J. P. Pelletier. 2000. The induction of cell death in human osteoarthritis chondrocytes by nitric oxide is related to the production of prostaglandin E2 via the induction of cyclooxygenase-2. J. Immunol. 165, 3402-3410.

23. Poole, A. R. 1999. An introduction to the pathophysiology of osteoarthritis. Front Biosci. 4, D662-670.

24. Sandell, L. J. and P. Adler. 1999. Developmental patterns of cartilage. Front Biosci. 4, D731-742.

25. Sandell, L. J. and T. Aigner. 2001. Articular cartilage and changes in arthritis. An introduction: cell biology of osteoarthritis. Arthritis Res. 3, 107-113.

26. Solursh, M. and S. Meier. 1973. The selective inhibition of mucopolysaccharide synthesis by vitamin A treatment of cultured chick embryo chondrocytes. Calcif. Tissue Res. 13, 131-142.

27. Tamura, T., T. Nakanishi, Y. Kimura, T. Hattori, K. Sasaki, H. Norimatsu, K. Takahashi, and M. Takigawa. 1996. Nitric oxide mediates interleukin-1-induced matrix degradation and basic fibroblast growth factor release in cultured rabbit articular chondrocytes: a possible mechanism of pathological neovascularization in arthritis. Endocrinology 137, 3729-3737.

28. Taskiran, D., M. Stefanovic-Racic, H. Georgescu, and C. Evans. 1994. Nitric oxide mediates suppression of cartilage proteoglycan synthesis by interleukin-1. Biochem Biophys. Res. Commun. 200, 142-148.

29. Tsonis, P. A., M. T. Sargent, K. Del Rio-Tsonis, and J. C. Jung. 1996. 9-cis retinoic acid antagonizes the stimulatory effect of 1,25 dihydroxyvitamin D3 on chondrogenesis of chick limb bud mesenchymal cells: interactions of their receptors. Int. J. Dev. Biol. 40, 1053-1059.

30. Underhill, T. M. and A. D. Weston. 1998. Retinoids and their receptors in skeletal development. Microsc. Res. Tech 43, 137-155.

31. Weston, A. D., V. Rosen, R. A. Chandraratna, and T. M. Underhill. 2000. Regulation of skeletal progenitor differentiation by the BMP and retinoid signaling pathways. $J$. Cell Biol. 148, 679-690.

32. Yoon, E. K., W. K. Lee, J. H. Lee, S. M. Yu, S. G. Hwang, and S. J. Kim. 2007. ERK-1/-2 and p38 kinase oppositely regulate 15-deoxy-delta(12,14)-prostaglandinJ(2)-Induced PPAR-gamma activation that mediates dedifferentiation but not cyclooxygenase-2 expression in articular chondrocytes. J. Korean Med. Sci. 22, 1015-1021.

33. Yoon, J. B., S. J. Kim, S. G. Hwang, S. Chang, S. S. Kang, and J. S. Chun. 2003. Non-steroidal anti-inflammatory drugs inhibit nitric oxide-induced apoptosis and dedifferentiation of articular chondrocytes independent of cyclooxygenase activity. J. Biol. Chem 278, 15319-15325. 
초록 : Retinoic acid의 ERK 신호전달경로를 통한 nitric oxide 유도 연골세포 탈분화 심화 기작

유선미 · 김송자*

(국립공주대학교 자연과학대학 생명과학과)

Retinoic acid (RA)는 Vitamin A의 대사산물로서 토끼 관절 연골세포의 탈분화를 유도하는 물질로 알려져 있 다. 그러나 RA가 탈분화를 조절하는 정확한 메커니즘은 잘 알려져 있지 않다. 따라서, Nitric Oxide (NO)가 유도 하는 탈분화에 미치는 RA의 분자적 기전에 관한 연구를 수행하였다. 그 결과, RA는 NO가 유도하는 탈분화를 촉진시키는 것을 확인 할 수 있었다. 이와 같은 결과는 Western blot analysis를 통해 연골세포 분화의 표지 단백 질인 type II collagen 및 Sox-9의 발현양상을 통해 확인 할 수 있었으며, Alcian blue staining을 통해 연골세포의 기질을 구성하고 있는 단백질인 sulfated proteoglycan의 발현량을 통해서도 확인 할 수 있었다. 또한, RA는 NO 가 유도하는 ERK의 활성을 더욱 증가 시켰다. ERK의 억제자인 PD98059를 사용하여 ERK의 활성을 억제하였을 때 RA가 감소시키는 type II collagen 및 Sox-9의 발현과 sulfated proteoglycan의 생성 양상이 PD98059에 의해 다시 회복되는 것을 확인 할 수 있었다. 이러한 모든 결과를 종합해 볼 때, RA는 NO가 유도하는 탈분화를 ERK 신호전달경로를 통해 조절하는 것을 확인 할 수 있었다. 